\title{
POTENTIAL INFLUENCE OF DIET ON BOMB-PULSE DATING OF HUMAN PLAQUE SAMPLES
}

\author{
Elisavet Andersson Georgiadou ${ }^{1,2} \bullet$ Isabel Gonçalves ${ }^{3,4} \bullet$ Cintia Bertacchi Uvo ${ }^{5}$ Jan Nilsson ${ }^{4}$ \\ Göran Skog ${ }^{6}$ - Sören Mattsson ${ }^{7}$ Luis M Pedro ${ }^{8}$ - José Fernandes e Fernandes ${ }^{8} \bullet$ \\ Kristina Eriksson Stenström ${ }^{1}$
}

\begin{abstract}
The radiocarbon concentration of different atherosclerotic plaque fragments obtained from 20 patients in Portugal, operated in 2000-2001, has been measured in order to define the year of plaque formation. A difference of 1.8-15 yr was observed, with the mean and median both $9 \mathrm{yr}$, between the bomb-pulse date estimated with the CALIBomb software and the operation date. Stable isotope $\left(\delta^{13} \mathrm{C}\right.$ and $\left.\delta^{15} \mathrm{~N}\right)$ analysis was also performed and provides insight to the diet of the subjects. The wide range of measured stable isotope values could indicate that the subjects' diet varied, including an abundance of marine foodstuffs. It could also mean a different isotope fractionation process for the different plaque fragments (cap, core, interface to media) and a possible difference in tissues in which the various fragments are formed. Analysis of $\delta^{13} \mathrm{C}$ and $\delta^{15} \mathrm{~N}$ values of each patient separately revealed subjects considered more influenced by marine foodstuffs consumption.
\end{abstract}

\section{INTRODUCTION}

The concentration of radiocarbon in the atmosphere dramatically increased during the late 1950s and early 1960s, reaching a maximum in 1963 due to testing of nuclear weapons in the atmosphere. The Limited Test Ban Treaty, signed in 1963, assured a significant reduction of nuclear weapon testing in the atmosphere. Consequently, atmospheric ${ }^{14} \mathrm{C}$ began to decrease quickly, principally because of its mixture with other large ${ }^{14} \mathrm{C}$ reservoirs, mainly the oceans and the biosphere. This bomb pulse of ${ }^{14} \mathrm{C}$ had a significant impact on all living matter (Hua and Barbetti 2004; Ubelaker and Buchholz 2005).

${ }^{14} \mathrm{C}$ is found in the atmosphere mostly in the form of ${ }^{14} \mathrm{CO}_{2} \cdot{ }^{14} \mathrm{CO}_{2}$ is absorbed by the vegetation and reaches animals and humans mainly through the food chain. It is generally expected that terrestrially living organisms, including humans, will contain a similar ${ }^{14} \mathrm{C} /{ }^{12} \mathrm{C}$ level as that of the local atmosphere at the time of formation, with only a small time lag. Therefore, the ${ }^{14} \mathrm{C}$ bomb pulse has become a valuable dating technique for tissues from the human body, revealing information about, for example, the material's formation date and the progress of an illness (Broecker et al. 1959; Libby et al. 1964; Harkness and Walton 1969; Nydal et al. 1971; Lynnerup et al. 2008; Gonçalves et al. 2010).

Bomb-pulse dating of human tissue typically uses clean-air atmospheric ${ }^{14} \mathrm{CO}_{2}$ data as a reference. However, as reported by Georgiadou and Stenström (2010) and Georgiadou et al. (2013), it is important to be aware that the diet of the subjects might affect the results. Carbon in terrestrial foodstuffs generally contains a higher concentration of ${ }^{14} \mathrm{C}$ than marine foodstuffs. This is due to the delay when atmospheric ${ }^{14} \mathrm{C}$ enters the oceans and the large size of the oceanic carbon reservoir (Georgia-

\footnotetext{
${ }^{1}$ Lund University, Department of Physics, Division of Nuclear Physics, Box 118, SE-221 00 Lund, Sweden.

${ }^{2}$ Corresponding author. Email: elisavet.georgiadou@nuclear.lu.se.

${ }^{3}$ Department of Cardiology, Skåne University Hospital, Malmö, Sweden.

${ }^{4}$ Cardiovascular Research Group, Department of Clinical Sciences, Malmö, Sweden.

${ }^{5}$ Lund University, Water Resources Engineering, Box 118, SE-221 00 Lund, Sweden.

${ }^{6}$ Lund University, Radiocarbon Dating Laboratory, Box 118, SE-221 00 Lund, Sweden.

${ }^{7}$ Lund University, Department of Clinical Sciences Malmö, Medical Radiation Physics, Skåne University Hospital, SE-205 02 Malmö, Sweden.

${ }^{8}$ Cardiovascular Institute of Lisbon, Lisbon, Portugal.
}

(c) 2013 by the Arizona Board of Regents on behalf of the University of Arizona Proceedings of the 21st International Radiocarbon Conference edited by A J T Jull \& C Hatté RADIOCARBON, Vol 55, Nr 2-3, 2013, p 874-884 


\section{E A Georgiadou et al.}

dou et al. 2013). Consequently, much of the marine foodstuff in the diet has the potential of producing bomb-pulse dates that are a few years younger than the true dates (Georgiadou and Stenström 2010). The opposite effect applies too, bomb-pulse dates older than the true dates can be caused by delay times through the food chain and consumption of stored food (Georgiadou et al. 2013). Local variations in the ${ }^{14} \mathrm{C}$ concentration, due to atmospheric releases from nuclear installations or other laboratories using ${ }^{14} \mathrm{C}$ materials, may also be important (Stenström et al. 2010).

Analysis of isotope fractionation of stable carbon and nitrogen isotopes $\left(\delta^{13} \mathrm{C}\right.$ and $\left.\delta^{15} \mathrm{~N}\right)$ using isotope ratio mass spectrometry (IRMS) can provide information on the diet of a subject (DeNiro and Epstein 1981; Tieszen 1983; Schoeller et al. 1986; Gearing 1991; Minagawa 1992; O’Connell 1996; Vanderklift and Ponsard 2003; Nash et al. 2012; Georgiadou et al. 2013). In bomb-pulse dating, this information can be valuable to detect extreme dietary conditions that might influence the ${ }^{14} \mathrm{C}$ date obtained from atmospheric calibration data (Georgiadou et al. 2013). Isotope fractionation arises during chemical and physical reactions due to the difference in mass between the different isotopes of an element (Schoeller 1999). Isotope fractionation of carbon occurs during photosynthesis and leads to considerably different ${ }^{13} \mathrm{C} /{ }^{12} \mathrm{C}$ ratios between plants from the $\mathrm{C}_{3}$ (e.g. wheat, potatoes) and the $\mathrm{C}_{4}$ (e.g. corn, sugarcane) food groups. Carbon isotope ratios differ between marine and terrestrial plants and consequently between animals living in aquatic and terrestrial environments. $\delta^{13} \mathrm{C}$ denotes the isotope fractionation of carbon and is defined as the relative deviation of the ${ }^{13} \mathrm{C} /{ }^{12} \mathrm{C}$ ratio of the sample compared to the respective ratio of a standard material (Tieszen et al. 1983).

As with carbon, isotope fractionation appears in nitrogen in different stages of the food chain, and is expressed as $\delta^{15} \mathrm{~N}$. This symbol refers to the comparison of the stable isotope ${ }^{15} \mathrm{~N}$ concentration of the samples with the common nitrogen isotope ${ }^{14} \mathrm{~N}$ (Georgiadou et al. 2013 and references therein). In humans, isotope fractionation between ingested food and human tissue is a complicated issue (Schoeller 1999) and depends, for example, on differences in the metabolic breakdown of the various ingested food components. Consequently, $\delta^{13} \mathrm{C}$ and $\delta^{15} \mathrm{~N}$ measurement may also provide indications about differences in the biochemical conversions in various human tissues.

In a study by Georgiadou et al. (2013), 60 human blood serum samples collected in 1978 from Swedish subjects with known dietary habits were bomb-pulse dated with the aim of estimating the accuracy of the technique. The difference $( \pm 1 \sigma)$ between the date estimated by bomb-pulse dating and the sampling date varied between $-3 \pm 0.4$ and $+0.2 \pm 0.5 \mathrm{yr}$. On average, the bomb-pulse dates obtained were $1.5 \pm 0.7 \mathrm{yr}$ older than the sampling dates. It was concluded that this effect could probably be attributed to the delay between production and consumption of foodstuffs. In addition to ${ }^{14} \mathrm{C}$ measurements, stable isotope analyses revealed information about the diet of the subjects, who were either omnivores, vegetarians, or lacto-ovo vegetarians (Georgiadou et al. 2013). Marine foodstuffs present both high $\delta^{15} \mathrm{~N}$ and $\delta^{13} \mathrm{C}$ values (Figure 1) as well as lower ${ }^{14} \mathrm{C}\left(\mathrm{F}^{14} \mathrm{C}\right)$ values (Reimer et al. 2004) compared to terrestrial foodstuffs. In general, the omnivores, who consume an excess of fish products in their diet, displayed higher $\delta^{15} \mathrm{~N}$ and $\delta^{13} \mathrm{C}$ values than the vegetarians and lacto-ovo vegetarians, who do not consume fish. Consequently, information on $\delta^{15} \mathrm{~N}$ and $\delta^{13} \mathrm{C}$ values can be a significant factor when interpreting ${ }^{14} \mathrm{C}$ data about the diet and consequently about the consumer. Furthermore, the study showed that the difference between the sampling date of the serum samples and the bomb-pulse date obtained from the ${ }^{14} \mathrm{C}$ measurement was strongly correlated to the $\delta^{13} \mathrm{C}$ values, probably due to the influence from marine diet components.

The current study performed ${ }^{14} \mathrm{C}$ bomb-pulse dating on 60 atherosclerotic plaque fragments of 20 patients from Portugal. Atherosclerotic plaque is an accumulation of fatty material in the intima of the arterial wall, which leads to an inflammatory response. Subsequently, smooth muscle cells from the media migrate and create a fibrous cap that surrounds the lipid and necrotic core (see Figure 2). 
Rupture of the fibrous cap leads to thrombosis, which may cause heart attacks through a blockage in the coronary arteries or strokes when thrombosis occurs in the carotid arteries.

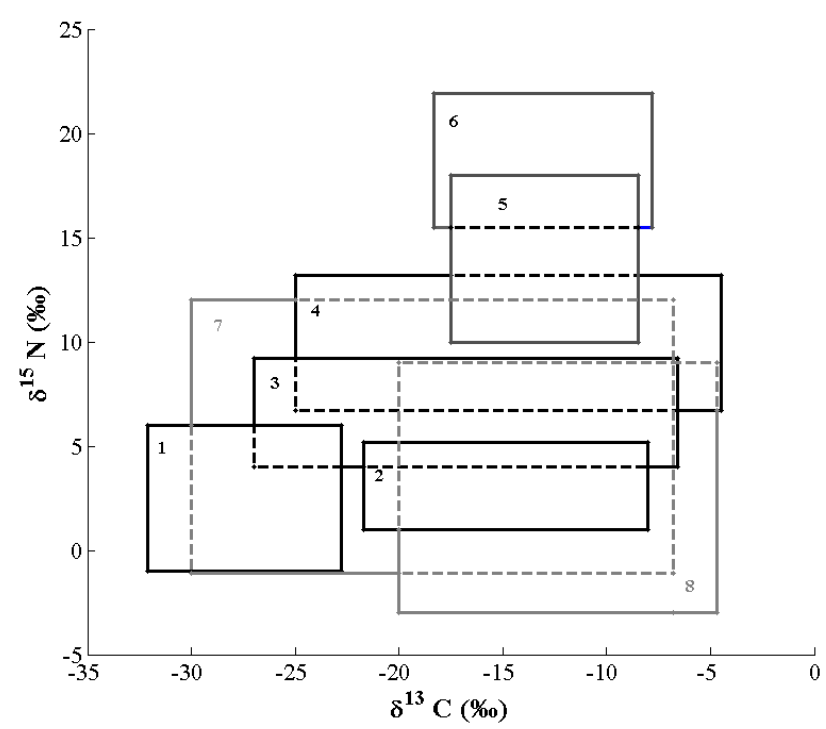

Figure 1 Generalized isotopic trophic level diagram for terrestrial and marine food webs: (1) $\mathrm{C}_{3}$ plants; (2) $\mathrm{C}_{4}$ plants; (3) $\mathrm{C}_{3}$ feeders-herbivores$\mathrm{C}_{4}$ grazers; (4) carnivores; (5) fish and birds; (6) sea mammals; (7) seaweed and zooplankton; (8) algae and phytoplankton. Adapted from O’Connell (1996) with permission.

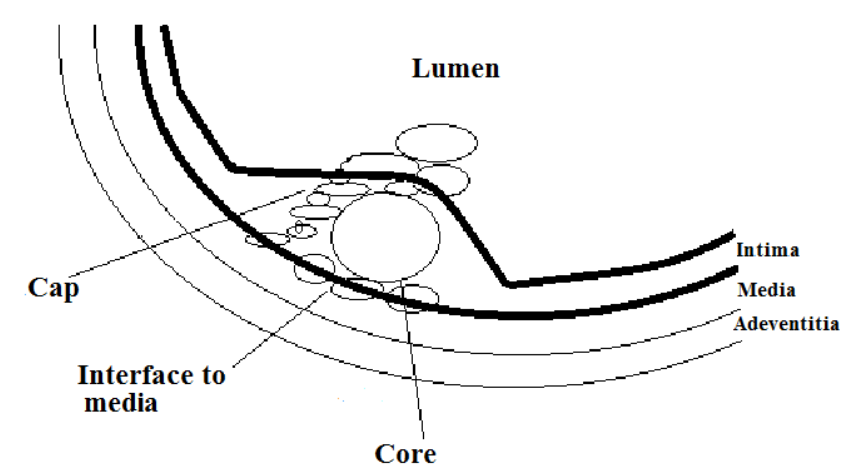

Figure 2 Cross-section of a human artery wall and fragments of the atherosclerotic plaque.

Gonçalves et al. (2010) used bomb-pulse dating to determine the age of different fragments of atherosclerotic plaque from 10 patients. The mean biological age of the cap fragment was $6.4 \pm 3.2 \mathrm{yr}$, which was significantly lower than those of the shoulder $(12.9 \pm 3.0 \mathrm{yr})$, the interface toward the media $(12.4 \pm 3.3 \mathrm{yr})$, and the core $(9.8 \pm 4.5 \mathrm{yr})$ fragments. In the present study, we obtained further age information about the gradual development of plaque by analyzing various plaque fragments from the 20 patients. Another aim was to investigate whether stable isotope analysis $\left(\delta^{13} \mathrm{C}, \delta^{15} \mathrm{~N}\right)$ could reveal useful information about the diet of the subjects. In particular, we aimed to evaluate whether the marine dietary effect, which has the potential of producing younger bomb-pulse dates 


\section{E A Georgiadou et al.}

compared to the sampling dates, could be substantial. We also aimed to investigate whether the various plaque fragments obtained from the same human subject displayed different $\delta^{13} \mathrm{C}$ and $\delta^{15} \mathrm{~N}$ values. This could either be attributed to isotope fractionation during the formation process of the different plaque fragments, or could be an effect of different cell types in the various fragments.

\section{MATERIALS AND METHODS}

\section{Subjects and Samples}

Human samples of different atherosclerotic plaque fragments were obtained from the Cardiovascular Institute of Lisbon, Portugal. All 20 patients had undergone surgery in 2000 and 2001 by endarterectomy because of a stenosis greater than $70 \%$ in the carotid arteries and the presence of symptoms ( $n=10$, such as strokes, transient ischemic attacks or amaurosis fugax) or because of a stenosis greater than $80 \%$ in the absence of symptoms. After surgical removal, the plaques were frozen in liquid nitrogen. Two 1-mm-thick transverse sections of the plaque were extracted, 1 for ${ }^{14} \mathrm{C}$ analysis and 1 for IRMS analysis. In order to facilitate the observation of a possible gradual development of the plaque, each section was dissected to separate the fibrous cap, core, and interface between the core and the underlying media of the plaque. No information was available about the dietary habits of the subjects.

\section{$\mathrm{F}^{14} \mathrm{C}$ Measurements of the Samples}

The plaque samples $(1.5-48.1 \mathrm{mg})$ were dried at $80^{\circ} \mathrm{C}$ for $1 \mathrm{hr}$. Some $1.2-1.6 \mathrm{mg}$ of each sample was converted to graphite as described in Genberg et al. (2010). Different treatment procedures were applied depending on the sample. For some samples analyzed early in the study, only parts were taken for analysis due to the large sample size. However, to eliminate the risk that this would not render the true mean age of the whole fragment of origin, this strategy was later abandoned in favor of analyzing the total sample. In some cases, the sample was split after combustion to $\mathrm{CO}_{2}$. In other cases, the sample was split prior to combustion in order to evaluate a possible variation in the age of the different parts of the sample and thus of the fragment of origin.

The graphite samples produced were pressed into small holders and analyzed in the Single Stage Accelerator Mass Spectrometer (SSAMS) at Lund University. Ox I was used as primary standard, C6 and C7 as secondary standards, and brown coal as the blank (Skog 2007; Skog et al. 2010). The generated $\mathrm{F}^{14} \mathrm{C}$ values were transformed into bomb-pulse ages using the CALIBomb program (Reimer et al. 2004) with the Northern Hemisphere zone 2 calibration data set (Hua and Barbetti 2004), using $0.5 \mathrm{yr}$ for both the smoothing and resolution parameters.

\section{$\delta^{13} \mathrm{C}$ and $\delta^{15} \mathrm{~N}$ Measurements of the Samples}

The samples were placed in glass tubes covered with only an aluminum foil sheet and placed in a preheated oven $\left(80^{\circ} \mathrm{C}\right)$ for $1 \mathrm{hr}$ to dry. All samples were cut into small pieces and fractions of each sample were placed in tin capsules (Säntis Analytical, SA76980502, 3.3 $\times 5 \mathrm{~mm}$ ) and weighed. The required weight of each sample was $0.25-0.3 \mathrm{mg}$. The tin capsules were then folded and placed in a numbered microwell plate. The samples were sent to the Environmental Isotope Laboratory (EIL) of the Earth and Environmental Science Division of the University of Waterloo, Ontario, Canada, for a $\delta^{13} \mathrm{C}$ and $\delta^{15} \mathrm{~N}$ analysis, using a Delta Plus, Continuous Flow IRMS (Meier-Augenstein 1999) connected to a Carlo Erba Elemental Analyzer (CHNS-O EA 1108, Italy).

$\delta^{15} \mathrm{~N}$ results were corrected to standards IAEA-N1 and IAEA-N2 (both ammonium sulfate) and $\delta^{13} \mathrm{C}$ was corrected to IAEA-CH6 (sugar) and EIL-72 (cellulose) standards, with added international 


\section{Influence of Diet on Bomb-Pulse Dating of Human Plaque}

and internal lab reference material. The accepted uncertainties are $\pm 0.3 \%$ for nitrogen and $\pm 0.2 \%$ for carbon, when clean ball-milled standard material is used. The uncertainty may increase according to the homogeneity, type, and amount of sample that is used (William Mark, personal communication, December 2011).

\section{RESULTS AND DISCUSSION}

The measured $\mathrm{F}^{14} \mathrm{C}, \delta^{13} \mathrm{C}$, and $\delta^{15} \mathrm{~N}$ values of the samples from every fragment (cap, core, and interface to media) are presented in Tables 1,2, and 3, respectively. For some of the cases, the plaque sample was split prior to ${ }^{14} \mathrm{C}$ analysis (Preparation 2 in Tables 1, 2, and 3), or only parts of the sample were analyzed (Preparation 3). A few of these split samples display a rather large variation in the mean biological age, while others show very similar values. The observed variation in age demonstrates that the plaque fragment has developed over a long time. For the most extreme cases, the difference in mean biological age of the split sample was more than $7 \mathrm{yr}$ (Table 2), so it should be kept in mind that the samples for which only some parts were analyzed (Preparation 3) do not necessarily represent the true mean biological age of the entire fragment.

Table $1 \delta^{13} \mathrm{C}, \delta^{15} \mathrm{~N}$, and $\mathrm{F}^{14} \mathrm{C}$ values for the plaque samples of the cap fragment. For the samples that were divided before combustion, the ${ }^{14} \mathrm{C}$ results of both cathodes are shown. Preparation: 1: Sample combusted as a whole; 2: Two pieces of the sample combusted separately; 3: Parts of sample combusted.

\begin{tabular}{|c|c|c|c|c|c|c|c|}
\hline \multirow[b]{2}{*}{$\begin{array}{l}\text { Year of } \\
\text { surgery }\end{array}$} & \multirow[b]{2}{*}{ Subject } & \multicolumn{2}{|c|}{ IRMS } & \multicolumn{3}{|c|}{${ }^{14} \mathrm{C}$ analysis } & \multirow[b]{2}{*}{$\begin{array}{l}\text { Age of plaque } \\
(y r)\end{array}$} \\
\hline & & $\begin{array}{l}\delta^{13} \mathrm{C} \\
(\%)\end{array}$ & $\begin{array}{l}\delta^{15} \mathrm{~N} \\
(\%)\end{array}$ & $\begin{array}{l}\text { Prepa- } \\
\text { ration }\end{array}$ & $\begin{array}{l}\mathrm{F}^{14} \mathrm{C} \\
(\text { mean } \pm 1 \sigma)\end{array}$ & $\begin{array}{l}\text { CALIBomb date } \\
(\text { mean } \pm 1 \sigma)\end{array}$ & \\
\hline 2000.33 & $\mathrm{~A}$ & -21.78 & 10.76 & 1 & $1.1398 \pm 0.0056$ & $1992.0 \pm 1.1$ & 8.33 \\
\hline 2000.33 & $\mathrm{~B}$ & -22.27 & 9.83 & 2 & $\begin{array}{l}1.1317 \pm 0.0079 \\
1.1136 \pm 0.0062\end{array}$ & $\begin{array}{l}1993.2 \pm 1.4 \\
1996.0 \pm 1.5\end{array}$ & $\begin{array}{l}7.13 \\
4.33\end{array}$ \\
\hline 2000.33 & $\mathrm{C}$ & -20.14 & 9.58 & 1 & $1.1091 \pm 0.0051$ & $1997.1 \pm 1.5$ & 3.23 \\
\hline 2000.33 & $\mathrm{D}$ & -20.01 & 11.99 & 1 & $1.1262 \pm 0.0061$ & $1996.4 \pm 1.3$ & 3.93 \\
\hline 2000.50 & $\mathrm{E}$ & -20.65 & 10.72 & 3 & $\begin{array}{l}1.1324 \pm 0.0072 \\
1.1163 \pm 0.0073\end{array}$ & $\begin{array}{l}1993.1 \pm 1.3 \\
1995.7 \pm 1.5\end{array}$ & $\begin{array}{l}7.40 \\
4.80\end{array}$ \\
\hline 2000.42 & $\mathrm{~F}$ & -20.74 & 11.93 & 1 & $1.1591 \pm 0.0054$ & $1989.7 \pm 1.3$ & 10.72 \\
\hline 2000.50 & $\mathrm{G}$ & -22.12 & 10.93 & 1 & $1.1134 \pm 0.0057$ & $1996.2 \pm 1.3$ & 4.30 \\
\hline 2000.92 & $\mathrm{H}$ & -20.96 & 12.44 & 1 & $1.1168 \pm 0.0056$ & $1995.7 \pm 1.4$ & 5.22 \\
\hline 2000.92 & I & -22.47 & 9.63 & 3 & $\begin{array}{l}1.1311 \pm 0.0076 \\
1.1571 \pm 0.0069\end{array}$ & $\begin{array}{l}1993.3 \pm 1.4 \\
1990.1 \pm 0.7\end{array}$ & $\begin{array}{r}7.62 \\
10.82\end{array}$ \\
\hline 2000.92 & $\mathrm{~J}$ & -19.48 & 12.83 & 3 & $\begin{array}{l}1.1225 \pm 0.0086 \\
1.1189 \pm 0.0061\end{array}$ & $\begin{array}{l}1994.6 \pm 1.5 \\
1994.9 \pm 1.2\end{array}$ & $\begin{array}{l}6.32 \\
6.02\end{array}$ \\
\hline 2000.92 & $\mathrm{~K}$ & -22.24 & 11.02 & 3 & $\begin{array}{l}1.1062 \pm 0.0083 \\
1.1161 \pm 0.0057\end{array}$ & $\begin{array}{l}1997.3 \pm 1.7 \\
1995.8 \pm 1.3\end{array}$ & $\begin{array}{l}3.62 \\
5.12\end{array}$ \\
\hline 2000.92 & $\mathrm{~L}$ & -20.02 & 12.63 & 1 & $1.0989 \pm 0.0082$ & $1999.1 \pm 1.8$ & 1.98 \\
\hline 2001.08 & M & -20.93 & 11.20 & 3 & $\begin{array}{l}1.1040 \pm 0.0076 \\
1.1082 \pm 0.0057\end{array}$ & $\begin{array}{l}1997.9 \pm 1.9 \\
1997.2 \pm 1.5\end{array}$ & $\begin{array}{l}3.27 \\
3.88\end{array}$ \\
\hline 2001.17 & $\mathrm{~N}$ & -19.69 & 11.12 & 1 & $1.1202 \pm 0.0061$ & $1994.7 \pm 1.2$ & 6.47 \\
\hline 2001.17 & $\mathrm{O}$ & -19.47 & 12.88 & 2 & $\begin{array}{l}1.1715 \pm 0.0075 \\
1.1561 \pm 0.0076\end{array}$ & $\begin{array}{l}1988.7 \pm 1.1 \\
1990.1 \pm 0.8\end{array}$ & $\begin{array}{l}12.47 \\
11.07\end{array}$ \\
\hline 2001.75 & $\mathrm{P}$ & -22.33 & 11.07 & 2 & $\begin{array}{l}1.1134 \pm 0.0068 \\
1.1204 \pm 0.0068\end{array}$ & $\begin{array}{l}1996.2 \pm 1.5 \\
1994.7 \pm 1.3\end{array}$ & $\begin{array}{l}5.55 \\
7.05\end{array}$ \\
\hline 2001.75 & Q & -22.24 & 10.05 & 1 & $1.1121 \pm 0.0059$ & $1996.4 \pm 1.3$ & 5.35 \\
\hline 2001.83 & $\mathrm{R}$ & -19.04 & 13.22 & 2 & $\begin{array}{l}1.1199 \pm 0.0074 \\
1.1292 \pm 0.0070\end{array}$ & $\begin{array}{l}1994.8 \pm 1.4 \\
1993.5 \pm 1.5\end{array}$ & $\begin{array}{l}7.03 \\
8.33\end{array}$ \\
\hline
\end{tabular}




\section{E A Georgiadou et al.}

Table $1 \delta^{13} \mathrm{C}, \delta^{15} \mathrm{~N}$, and $\mathrm{F}^{14} \mathrm{C}$ values for the plaque samples of the cap fragment. For the samples that were divided before combustion, the ${ }^{14} \mathrm{C}$ results of both cathodes are shown. Preparation: 1 : Sample combusted as a whole; 2: Two pieces of the sample combusted separately; 3: Parts of sample combusted. (Continued)

\begin{tabular}{|c|c|c|c|c|c|c|c|}
\hline \multirow[b]{2}{*}{$\begin{array}{l}\text { Year of } \\
\text { surgery }\end{array}$} & \multirow[b]{2}{*}{ Subject } & \multicolumn{2}{|c|}{ IRMS } & \multicolumn{3}{|c|}{${ }^{14} \mathrm{C}$ analysis } & \multirow[b]{2}{*}{$\begin{array}{l}\text { Age of plaque } \\
(\mathrm{yr})\end{array}$} \\
\hline & & $\begin{array}{l}\delta^{13} \mathrm{C} \\
(\%)\end{array}$ & $\begin{array}{l}\delta^{15} \mathrm{~N} \\
(\% 0)\end{array}$ & $\begin{array}{l}\text { Prepa- } \\
\text { ration }\end{array}$ & $\begin{array}{l}\mathrm{F}^{14} \mathrm{C} \\
(\text { mean } \pm 1 \sigma)\end{array}$ & $\begin{array}{l}\text { CALIBomb date } \\
(\text { mean } \pm 1 \sigma)\end{array}$ & \\
\hline 2001.92 & $\mathrm{~S}$ & -20.81 & 11.37 & 2 & $\begin{array}{l}1.1569 \pm 0.0068 \\
1.1249 \pm 0.0075\end{array}$ & $\begin{array}{l}1990.1 \pm 0.7 \\
1994.3 \pm 1.3\end{array}$ & $\begin{array}{r}11.82 \\
7.62\end{array}$ \\
\hline 2001.92 & $\mathrm{~T}$ & -23.23 & 10.58 & 2 & $\begin{array}{l}1.1104 \pm 0.0064 \\
1.1204 \pm 0.0078\end{array}$ & $\begin{aligned} 1997.0 & \pm 1.7 \\
1994.7 & \pm 1.4 \\
& \text { Mean age }\end{aligned}$ & $\begin{array}{l}4.92 \\
7.22 \\
5.54\end{array}$ \\
\hline
\end{tabular}

Table $2 \delta^{13} \mathrm{C}, \delta^{15} \mathrm{~N}$, and $\mathrm{F}^{14} \mathrm{C}$ values for the plaque samples of the core fragment. For the samples that were divided before combustion, the ${ }^{14} \mathrm{C}$ results of both cathodes are shown. Preparation: 1: Samples combusted as a whole; 2: Two pieces of the sample combusted separately; 3: Parts of sample combusted.

\begin{tabular}{|c|c|c|c|c|c|c|c|}
\hline \multirow[b]{2}{*}{$\begin{array}{l}\text { Year of } \\
\text { surgery }\end{array}$} & \multirow[b]{2}{*}{ Subject } & \multicolumn{2}{|c|}{ IRMS } & \multicolumn{3}{|c|}{${ }^{14} \mathrm{C}$ analysis } & \multirow[b]{2}{*}{$\begin{array}{l}\text { Age of plaque } \\
(\mathrm{yr})\end{array}$} \\
\hline & & $\begin{array}{l}\delta^{13} \mathrm{C} \\
(\% 0)\end{array}$ & $\begin{array}{l}\delta^{15} \mathrm{~N} \\
(\% 0)\end{array}$ & $\begin{array}{l}\text { Prepa- } \\
\text { ration }\end{array}$ & $\begin{array}{l}\mathrm{F}^{14} \mathrm{C} \\
(\text { mean } \pm 1 \sigma)\end{array}$ & $\begin{array}{l}\text { CALIBomb date } \\
(\text { mean } \pm 1 \sigma)\end{array}$ & \\
\hline 2000.33 & A & -23.01 & 9.04 & 2 & $\begin{array}{l}1.1576 \pm 0.0079 \\
1.1635 \pm 0.0068\end{array}$ & $\begin{array}{l}1990.0 \pm 0.8 \\
1989.6 \pm 0.8\end{array}$ & $\begin{array}{l}10.33 \\
10.73\end{array}$ \\
\hline 2000.33 & $\mathrm{~B}$ & -22.76 & 9.37 & 2 & $\begin{array}{l}1.1198 \pm 0.0078 \\
1.1386 \pm 0.0062\end{array}$ & $\begin{array}{l}1994.8 \pm 1.5 \\
1992.1 \pm 1.1\end{array}$ & $\begin{array}{l}5.53 \\
8.23\end{array}$ \\
\hline 2000.33 & $\mathrm{C}$ & -21.21 & no data & 2 & $\begin{array}{l}1.1652 \pm 0.0062 \\
1.1373 \pm 0.0061\end{array}$ & $\begin{array}{l}1989.4 \pm 0.8 \\
1992.1 \pm 1.1\end{array}$ & $\begin{array}{r}10.93 \\
8.23\end{array}$ \\
\hline 2000.33 & $\mathrm{D}$ & -21.62 & 10.02 & 2 & $\begin{array}{l}1.1243 \pm 0.0063 \\
1.1626 \pm 0.0064\end{array}$ & $\begin{array}{l}1997.1 \pm 1.6 \\
1990.9 \pm 0.8\end{array}$ & $\begin{array}{l}3.23 \\
9.43\end{array}$ \\
\hline 2000.50 & $\mathrm{E}$ & -21.71 & 9.52 & 3 & $\begin{array}{l}1.1134 \pm 0.0071 \\
1.1106 \pm 0.0069\end{array}$ & $\begin{array}{l}1996.2 \pm 1.5 \\
1997.2 \pm 1.4\end{array}$ & $\begin{array}{l}4.3 \\
3.3\end{array}$ \\
\hline 2000.42 & $\mathrm{~F}$ & -21.07 & 11.83 & 1 & $1.1260 \pm 0.0060$ & $1994.2 \pm 1.1$ & 6.22 \\
\hline 2000.50 & G & -19.88 & no data & 1 & $1.1858 \pm 0.0103$ & $1987.1 \pm 1.3$ & 13.4 \\
\hline 2000.92 & $\mathrm{H}$ & -21.29 & 10.91 & 1 & $1.1561 \pm 0.0057$ & $1990.2 \pm 0.6$ & 10.72 \\
\hline 2000.92 & I & -22.13 & 10.94 & 2 & $\begin{array}{l}1.1532 \pm 0.0083 \\
1.2152 \pm 0.0080\end{array}$ & $\begin{array}{l}1990.7 \pm 1.1 \\
1984.4 \pm 0.6\end{array}$ & $\begin{array}{l}10.22 \\
16.52\end{array}$ \\
\hline 2000.92 & $\mathrm{~J}$ & -20.30 & 10.06 & 2 & $\begin{array}{l}1.1572 \pm 0.0081 \\
1.1518 \pm 0.0062\end{array}$ & $\begin{array}{l}1990.1 \pm 0.9 \\
1990.8 \pm 0.9\end{array}$ & $\begin{array}{l}10.82 \\
10.12\end{array}$ \\
\hline 2000.92 & $\mathrm{~K}$ & -22.36 & 10.57 & 3 & $\begin{array}{l}1.1236 \pm 0.0077 \\
1.1010 \pm 0.0140\end{array}$ & $\begin{array}{l}1994.4 \pm 1.3 \\
1998.4 \pm 2.7\end{array}$ & $\begin{array}{l}6.52 \\
2.52\end{array}$ \\
\hline 2000.92 & $\mathrm{~L}$ & -19.58 & 11.64 & 1 & $1.1256 \pm 0.0077$ & $1994.3 \pm 1.3$ & 6.62 \\
\hline 2001.08 & M & -22.08 & 11.18 & 3 & $1.1288 \pm 0.0058^{\mathrm{a}}$ & $1993.9 \pm 1.0$ & 7.18 \\
\hline 2001.17 & $\mathrm{~N}$ & no data & no data & 1 & $1.1585 \pm 0.0087$ & $1989.9 \pm 0.9$ & 11.27 \\
\hline 2001.17 & $\mathrm{O}$ & -20.42 & 12.05 & 2 & $\begin{array}{l}1.1500 \pm 0.0071 \\
1.1631 \pm 0.0067\end{array}$ & $\begin{array}{l}1990.9 \pm 0.9 \\
1989.6 \pm 0.8\end{array}$ & $\begin{array}{l}10.27 \\
11.57\end{array}$ \\
\hline 2001.75 & $\mathrm{P}$ & -21.78 & 11.39 & 2 & $\begin{array}{l}1.1204 \pm 0.0069 \\
1.1305 \pm 0.0078\end{array}$ & $\begin{array}{l}1994.7 \pm 1.3 \\
1993.3 \pm 1.4\end{array}$ & $\begin{array}{l}7.05 \\
8.45\end{array}$ \\
\hline 2001.75 & Q & -22.39 & 9.65 & 2 & $\begin{array}{l}1.1420 \pm 0.0071 \\
1.1549 \pm 0.0067\end{array}$ & $\begin{array}{l}1991.9 \pm 1.1 \\
1990.2 \pm 0.7\end{array}$ & $\begin{array}{r}9.85 \\
11.55\end{array}$ \\
\hline 2001.83 & $\mathrm{R}$ & -19.83 & 12.76 & 2 & $\begin{array}{l}1.2159 \pm 0.0072 \\
1.1459 \pm 0.0070\end{array}$ & $\begin{array}{l}1984.3 \pm 0.6 \\
1991.6 \pm 1.2\end{array}$ & $\begin{array}{l}17.53 \\
10.23\end{array}$ \\
\hline 2001.92 & $\mathrm{~S}$ & -19.76 & 10.73 & 2 & $\begin{array}{l}1.1487 \pm 0.0070 \\
1.1888 \pm 0.0075\end{array}$ & $\begin{array}{l}1991.4 \pm 1.3 \\
1986.9 \pm 1.1\end{array}$ & $\begin{array}{l}17.62 \\
10.32\end{array}$ \\
\hline 2001.92 & $\mathrm{~T}$ & -23.19 & 10.28 & 3 & $1.1177 \pm 0.0065^{\mathrm{a}}$ & $\begin{array}{r}1995.5 \pm 1.6 \\
\text { Mean age }\end{array}$ & $\begin{array}{l}6.42 \\
7.79\end{array}$ \\
\hline
\end{tabular}

${ }^{\mathrm{a}} \mathrm{F}^{14} \mathrm{C}$ measurement for only 1 part of the sample. 


\section{Influence of Diet on Bomb-Pulse Dating of Human Plaque}

Table $3 \delta^{13} \mathrm{C}, \delta^{15} \mathrm{~N}$, and $\mathrm{F}^{14} \mathrm{C}$ values for the plaque samples of the interface to media fragment. For the samples that were divided before combustion, the ${ }^{14} \mathrm{C}$ results of both cathodes are shown. Preparation: 1: Sample combusted as a whole; 2: Two pieces of the sample combusted separately; 3: Parts of sample combusted.

\begin{tabular}{|c|c|c|c|c|c|c|c|}
\hline \multirow[b]{2}{*}{$\begin{array}{l}\text { Year of } \\
\text { surgery }\end{array}$} & \multirow[b]{2}{*}{ Subject } & \multicolumn{2}{|c|}{ IRMS } & \multicolumn{3}{|c|}{${ }^{14} \mathrm{C}$ analysis } & \multirow[b]{2}{*}{$\begin{array}{l}\text { Age of plaque } \\
(\mathrm{yr})\end{array}$} \\
\hline & & $\begin{array}{l}\delta^{13} \mathrm{C} \\
(\% 0)\end{array}$ & $\begin{array}{l}\delta^{15} \mathrm{~N} \\
(\%)\end{array}$ & $\begin{array}{l}\text { Prepa- } \\
\text { ration }\end{array}$ & $\begin{array}{l}\mathrm{F}^{14} \mathrm{C} \\
(\text { mean } \pm 1 \sigma)\end{array}$ & $\begin{array}{l}\text { CALIBomb date } \\
(\text { mean } \pm 1 \sigma)\end{array}$ & \\
\hline 2000.33 & A & -21.21 & 10.96 & 1 & $1.1814 \pm 0.0055$ & $1987.3 \pm 1.0$ & 13.03 \\
\hline 2000.33 & $\mathrm{~B}$ & -21.99 & 11.10 & 1 & $1.1541 \pm 0.0055$ & $1990.4 \pm 0.6$ & 9.93 \\
\hline 2000.33 & $\mathrm{C}$ & -22.16 & 9.29 & 2 & $\begin{array}{l}1.2010 \pm 0.0063 \\
1.1744 \pm 0.0061\end{array}$ & $\begin{array}{l}1984.6 \pm 0.6 \\
1988.3 \pm 1.0\end{array}$ & $\begin{array}{l}15.73 \\
12.03\end{array}$ \\
\hline 2000.33 & $\mathrm{D}$ & -20.43 & 12.18 & 1 & $1.1362 \pm 0.0062$ & $1993.5 \pm 2.9$ & 6.83 \\
\hline 2000.50 & $\mathrm{E}$ & -20.11 & 12.46 & 3 & $\begin{array}{l}1.1383 \pm 0.0078 \\
1.1716 \pm 0.0059\end{array}$ & $\begin{array}{l}1992.1 \pm 1.2 \\
1988.8 \pm 0.9\end{array}$ & $\begin{array}{r}8.4 \\
11.7\end{array}$ \\
\hline 2000.42 & $\mathrm{~F}$ & -19.81 & 13.77 & 2 & $\begin{array}{l}1.1523 \pm 0.0087 \\
1.1597 \pm 0.0066\end{array}$ & $\begin{array}{l}1990.7 \pm 1.1 \\
1989.9 \pm 0.7\end{array}$ & $\begin{array}{r}9.72 \\
10.52\end{array}$ \\
\hline 2000.50 & $\mathrm{G}$ & -20.25 & 12.78 & 1 & $1.1831 \pm 0.0057$ & $1987.2 \pm 1.0$ & 13.3 \\
\hline 2000.92 & $\mathrm{H}$ & -20.20 & 12.77 & 1 & $1.1566 \pm 0.0057$ & $1990.2 \pm 0.6$ & 10.72 \\
\hline 2000.92 & I & -19.92 & 13.56 & 3 & $\begin{array}{l}1.1114 \pm 0.0077 \\
1.1791 \pm 0.0061\end{array}$ & $\begin{array}{l}1996.9 \pm 1.8 \\
1989.9 \pm 0.0\end{array}$ & $\begin{array}{r}4.02 \\
11.02\end{array}$ \\
\hline 2000.92 & $\mathrm{~J}$ & -19.55 & 12.60 & 3 & $\begin{array}{l}1.1520 \pm 0.0086 \\
1.1604 \pm 0.0058\end{array}$ & $\begin{array}{l}1990.7 \pm 1.1 \\
1989.9 \pm 0.7\end{array}$ & $\begin{array}{l}10.22 \\
11.02\end{array}$ \\
\hline 2000.92 & $\mathrm{~K}$ & -21.02 & 12.41 & 3 & $\begin{array}{l}1.1448 \pm 0.0078 \\
1.1345 \pm 0.0058\end{array}$ & $\begin{array}{l}1991.7 \pm 1.2 \\
1992.4 \pm 1.3\end{array}$ & $\begin{array}{l}9.22 \\
8.52\end{array}$ \\
\hline 2000.92 & $\mathrm{~L}$ & -21.40 & 11.80 & 3 & $\begin{array}{l}1.1375 \pm 0.0078 \\
1.1799 \pm 0.0061\end{array}$ & $\begin{array}{l}1992.2 \pm 1.3 \\
1987.5 \pm 1.1\end{array}$ & $\begin{array}{r}8.72 \\
13.42\end{array}$ \\
\hline 2001.08 & M & -20.63 & 13.18 & 3 & $\begin{array}{l}1.1331 \pm 0.0083 \\
1.1386 \pm 0.0082\end{array}$ & $\begin{array}{l}1992.7 \pm 1.6 \\
1992.1 \pm 1.2\end{array}$ & $\begin{array}{l}8.38 \\
8.98\end{array}$ \\
\hline 2001.17 & $\mathrm{~N}$ & -19.53 & 11.81 & 1 & $1.1246 \pm 0.0068$ & $1994.3 \pm 1.2$ & 5.87 \\
\hline 2001.17 & $\mathrm{O}$ & -19.86 & 13.51 & 2 & $\begin{array}{l}1.1552 \pm 0.0070 \\
1.1831 \pm 0.0072\end{array}$ & $\begin{array}{l}1990.2 \pm 0.7 \\
1987.2 \pm 1.1\end{array}$ & $\begin{array}{l}10.97 \\
13.97\end{array}$ \\
\hline 2001.75 & $\mathrm{P}$ & -21.10 & 11.47 & 2 & $\begin{array}{l}1.1145 \pm 0.0010 \\
1.1338 \pm 0.0071\end{array}$ & $\begin{array}{l}1995.9 \pm 1.9 \\
1992.6 \pm 1.5\end{array}$ & $\begin{array}{l}5.85 \\
9.15\end{array}$ \\
\hline 2001.75 & Q & -22.25 & 9.69 & 3 & $1.1391 \pm 0.0068^{\mathrm{a}}$ & $1992.0 \pm 1.1$ & 9.75 \\
\hline 2001.83 & $\mathrm{R}$ & -19.14 & 13.24 & 2 & $\begin{array}{l}1.1413 \pm 0.0067 \\
1.1496 \pm 0.0069\end{array}$ & $\begin{array}{l}1991.9 \pm 1.1 \\
1991.0 \pm 0.9\end{array}$ & $\begin{array}{r}9.93 \\
10.83\end{array}$ \\
\hline 2001.92 & $\mathrm{~S}$ & -20.49 & 12.28 & 1 & $1.1361 \pm 0.0059$ & $1992.2 \pm 1.2$ & 9.72 \\
\hline 2001.92 & $\mathrm{~T}$ & -21.24 & 11.2 & 2 & $\begin{array}{l}1.1436 \pm 0.0074 \\
1.1956 \pm 0.0068\end{array}$ & $\begin{array}{l}1991.8 \pm 1.2 \\
1986.0 \pm 0.9\end{array}$ & $\begin{array}{l}10.12 \\
15.92\end{array}$ \\
\hline & & & & & & Mean age & 9.74 \\
\hline
\end{tabular}

The $\mathrm{F}^{14} \mathrm{C}$ averages for each of the 3 plaque fragments - cap, core, and interface to media - of all the subjects are presented in Table 4. The years of formation, calculated using CALIBomb software (Reimer et al. 2004), demonstrate, in general, that the cap fragment is the youngest, while the interface to media fragment develops first and is therefore the oldest. These results are in accordance with the earlier studies of Gonçalves et al. (2010).

Table $4 \mathrm{~F}^{14} \mathrm{C}$ average values and predicted date from CALIBomb for the 3 plaque fragments (cap, core, interface to media) of all the subjects.

\begin{tabular}{lll}
\hline Fragment & $\mathrm{F}^{14} \mathrm{C}$ & Mean age $(\mathrm{yr})$ \\
\hline Cap & $1.125 \pm 0.016$ & $5.54 \pm 2.6$ \\
Core & $1.143 \pm 0.022$ & $7.79 \pm 3.7$ \\
Interface to media & $1.153 \pm 0.019$ & $9.74 \pm 2.4$ \\
\hline
\end{tabular}




\section{E A Georgiadou et al.}

One of the aims of the present study was to investigate whether stable isotope analysis could reveal information about dietary habits, in particular whether marine food intake could produce bombpulse dates that were too young in relation to the sampling date. In the study of human serum samples by Georgiadou et al. (2013), 2 groups of data were distinguished from the stable isotope analysis. One group consisted of samples from omnivore subjects, while the other group consisted of samples from the pooled group of lacto-ovo vegetarian and vegan subjects. Figure 3 shows the boundaries of these groups (obtained from the Swedish serum samples) as well as the measured $\delta^{13} \mathrm{C}$ and $\delta^{15} \mathrm{~N}$ values of the Portuguese plaque samples. The Portuguese plaque samples have a wider range than the Swedish serum samples in the $\delta^{13} \mathrm{C}$ and $\delta^{15} \mathrm{~N}$ values. This seems reasonable considering that different kinds of samples are used in the 2 studies, meaning different metabolism and possibly different isotope fractionation. Another interpretation is that the Portuguese subjects consume more marine foods in their diet than the Swedish subjects (in general marine foodstuffs have higher $\delta^{13} \mathrm{C}$ and $\delta^{15} \mathrm{~N}$ values than terrestrially produced food, see Figure 1). In fact, the Swedish subjects that donated serum samples are expected to consume more $C_{3}$ than $C_{4}$ vegetables, according to the Swedish diet trend described by the Food and Agricultural Organization of the United Nations (FAO 2012). On the other hand, the Portuguese plaque subjects are expected to follow the Portuguese diet trend, consuming more fish and maize products (Carvalho 1995; MarquesVidal et al. 2006; FAO 2012). The Swedish serum samples (Figure 3) all showed CALIBomb ages that were older than the sampling date. This was interpreted as a result of the time lag effect (delay between production and consumption of food) being larger than any marine effect (which would produce dates that were too young) (Georgiadou et al. 2013). In the present study, however, the relatively high $\delta^{13} \mathrm{C}$ and $\delta^{15} \mathrm{~N}$ values of some of the Portuguese plaque samples might imply that the marine effect is sufficiently dominant to produce dates that are younger in relation to the sampling dates. It should also be noted that there may be a possible individual variation in the diet of the subjects of this study, since the sample $\delta^{13} \mathrm{C}$ and $\delta^{15} \mathrm{~N}$ values of all the fragments are widely distributed, as can be seen in Figure 3.

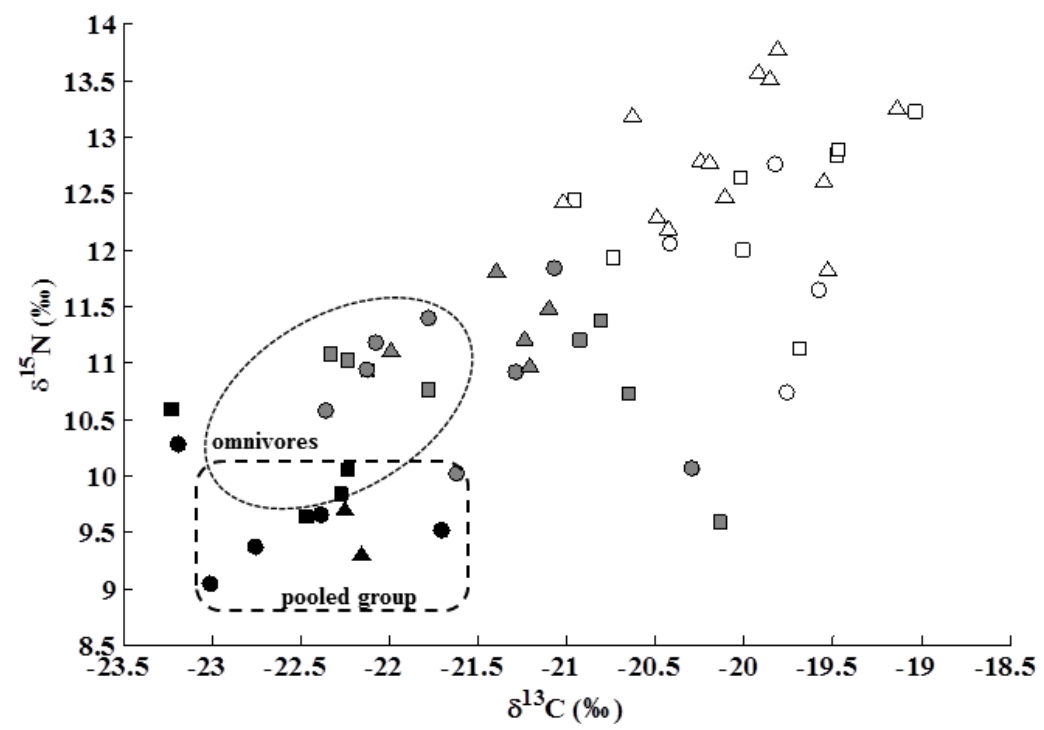

Figure 3 The 3 groups (black, gray, and white) created by cluster analysis in a $\delta^{13} \mathrm{C}$ and $\delta^{15} \mathrm{~N}$ diagram (squares: cap fragments; circles: core fragments; triangles: interface to media fragments) and omnivore and pooled (vegan and lacto-ovo vegetarian) group boundaries from a study of Swedish serum samples Georgiadou et al. (2013). 


\section{Influence of Diet on Bomb-Pulse Dating of Human Plaque}

Statistical cluster analysis was also applied to the data to reveal subgroups with similarities. Cluster analysis splits data elements into subgroups based on similarities and differences. This can lead to new data stratification that otherwise may have been ignored (Wilks 2006).

In this study, cluster analysis (Figure 3) was based on the $\delta^{13} \mathrm{C}$ and $\delta^{15} \mathrm{~N}$ values of the samples, and separated the samples clearly into 3 groups, although not based on any of their known characteristics. No particular result of marine influence on any fragment group or subgroup could be determined, as had been observed in the serum sample analysis by Georgiadou et al. (2013), since all fragment samples are found in all the subgroups. The cluster analysis therefore did not reveal any clear marine influence.

An additional investigation of the $\delta^{13} \mathrm{C}$ and $\delta^{15} \mathrm{~N}$ values of all the samples of each patient separately was also carried out (Figures 4a,b). For the majority of subjects, the core fragments have the lowest values for both $\delta^{13} \mathrm{C}$ and $\delta^{15} \mathrm{~N}$. Cap fragments are next, then finally the interface to media fragments, although a few exceptions were detected. This pattern could indicate differences in isotope fractionation in the biochemical processes involved in the formation of the different plaque fragments, or could be an effect of different tissues in the various fragments.
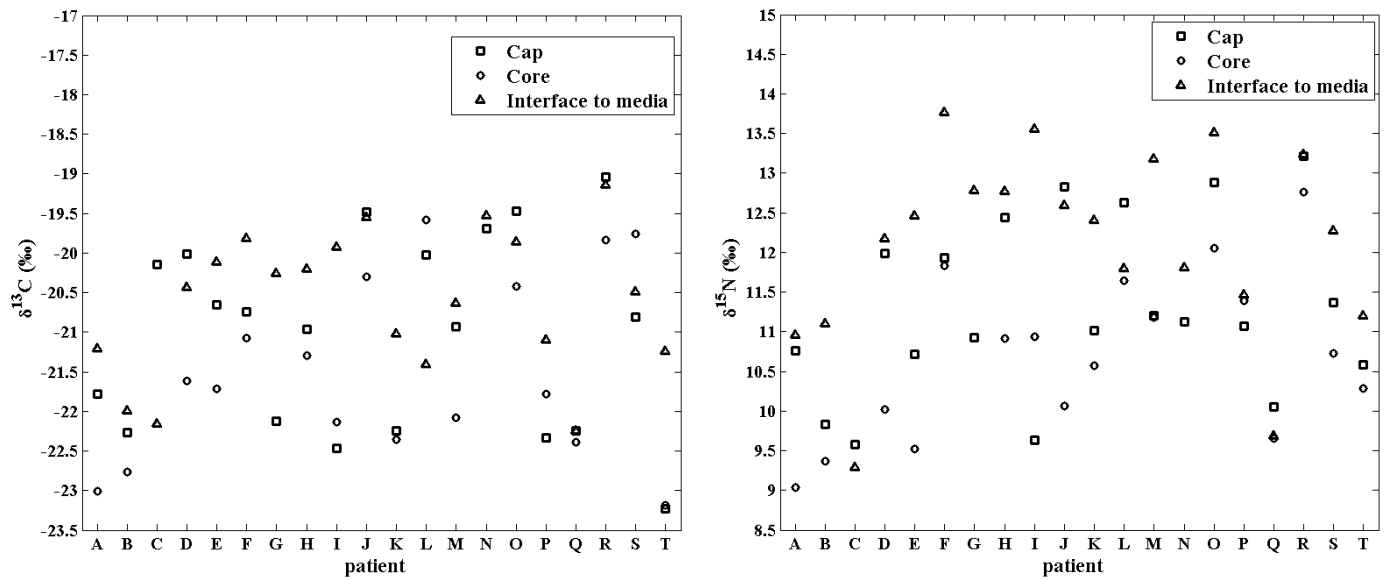

Figure 4 The $\delta^{13} \mathrm{C}$ (a) and $\delta^{15} \mathrm{~N}$ (b) values of the 3 plaque fragment samples for each subject separately.

Subjects Q and R (Figures 4a,b) illustrate how the results of the stable isotope analysis can be interpreted and show how conclusions can be drawn regarding the subjects' diet. Subject $\mathrm{Q}$ has relatively low $\delta^{13} \mathrm{C}$ and $\delta^{15} \mathrm{~N}$ values, while the plaque fragments of subject R have relatively high $\delta^{13} \mathrm{C}$ and $\delta^{15} \mathrm{~N}$ values. Bearing in mind the isotopic trophic level diagram (Figure 1), it should be expected that subject $Q$ possibly eats more vegetables from the $\mathrm{C}_{3}$ food group, while subject $\mathrm{R}$ possibly eats more marine foodstuffs. Marine food consumption could be a reason to expect lower $\mathrm{F}^{14} \mathrm{C}$ concentration in the samples, leading to younger CALIBomb dates than the true ages. This conclusion is confirmed by the results deducted for serum samples (Georgiadou et al. 2013) for which a significant correlation between the $\delta^{13} \mathrm{C}$ and the age deviation (difference of sampling date from the CALIBomb date) was found, although the subjects in the 2 different cases are expected to follow different dietary trends. 


\section{E A Georgiadou et al.}

\section{CONCLUSIONS}

$\mathrm{F}^{14} \mathrm{C}$ measurements of human plaque samples taken from operations in 2000-2001 demonstrated higher values than the respective atmospheric ${ }^{14} \mathrm{C}$ concentrations. CALIBomb analysis, using atmospheric ${ }^{14} \mathrm{C}$ data as a reference, showed that the plaque fragments were formed 1.98 to $17.62 \mathrm{yr}$ before the operation date. On average, the cap fragments were found to be the youngest (1.98-12.47 yr old). The core fragments were older and had a wider age range (2.52-17.62 yr old), while the oldest in most cases appeared to be the interface to media fragments (4.02-15.92 yr old). This result is in accordance with that found by Gonçalves et al. (2010).

Stable isotope analysis revealed that the plaque samples from the Portuguese subjects showed a wider range of $\delta^{13} \mathrm{C}$ and $\delta^{15} \mathrm{~N}$ than a study of serum samples from Swedish citizens (Georgiadou et al. 2013). This can be interpreted either as a metabolic effect or a dietary effect, or a combination of the two. The known general dietary habits of the 2 countries support the idea of a dietary effect according to nationality being apparent in the data. The data suggests that the Portuguese consume more fish products than the Swedes. If the dietary effect is indeed dominant, there is a risk that the CALIBomb software, using atmospheric ${ }^{14} \mathrm{C}$ data as a reference, produces bomb-pulse dates that are younger compared to the sampling dates for subjects consuming a relatively large proportion of fish products. A metabolic effect (or cell type effect) is also supported by a general pattern in the $\delta^{13} \mathrm{C}$ and $\delta^{15} \mathrm{~N}$ values of the different plaque fragments of each patient: core fragments display the lowest values followed by cap fragments, and then interface to media fragments, although a few exceptions are detected. To investigate which of the 2 effects (metabolic effect or dietary effect) is dominant, we plan to analyze plaque samples from Swedish citizens.

Additional analysis of the $\delta^{13} \mathrm{C}$ and $\delta^{15} \mathrm{~N}$ values of each patient's plaque fragments separately lead to the conclusion that stable isotope analysis could provide information about the diet of the subjects. Specifically, it could potentially reveal the samples whose CALIBomb date may be influenced by the consumption of marine foodstuffs.

\section{ACKNOWLEDGMENTS}

We thank the Swedish Research Council (VR) dnr 2009-4702, Marianne and Marcus Wallenberg Foundation, Swedish Heart and Lung Foundation, the Swedish Strategic Research Foundation, Swedish Medical Society, Regional research funds (Region Skåne), Malmö University Hospital funds and Ernhold Lundström's Foundation for the financial support to this study, and the laboratory assistant Mattias Olsson for his help.

\section{REFERENCES}

Broecker WS, Schulert A, Olson EA. 1959. Bomb carbon-14 in human beings. Science 130(3371):331-2.

Carvalho FP. 1995. ${ }^{210} \mathrm{Po}$ and ${ }^{210} \mathrm{~Pb}$ intake by the Portuguese population: the contribution of seafood in the dietary intake of ${ }^{210} \mathrm{Po}$ and ${ }^{210} \mathrm{~Pb}$. Health Physics 69(4):469-80.

DeNiro MJ, Epstein S. 1981. Influence of diet on the distribution of nitrogen isotopes in animals. Geochimica et Cosmochimica Acta 45(3):341-51.

Food and Agriculture Organization (FAO) of the United Nations. 2012. Food Balance Sheets: Portugal, Sweden, 2000-01, Food Supply. URL: http:// faostat.fao.org/site/368/DesktopDefault.aspx. Accessed April 2012
Gearing JN. 1991. The study of diet and trophic relationships through natural abundance ${ }^{13} \mathrm{C}$. In: Coleman DC, Fry B, editors. Carbon Isotope Techniques. London: Academic Press. p 201-17.

Genberg J, Stenström K, Elfman M, Olsson M. 2010. Development of graphitization of $\mu \mathrm{g}$-sized samples at Lund University. Radiocarbon 52(3):1270-6.

Georgiadou E, Stenström K. 2010. Bomb-pulse dating of human material: modeling the influence of diet. $R a-$ diocarbon 52(2):800-7.

Georgiadou E, Eriksson Stenström K, Bertacchi Uvo C, Nilsson P, Skog G, Mattsson S. 2013. Bomb-pulse ${ }^{14} \mathrm{C}$ analysis combined with ${ }^{13} \mathrm{C}$ and ${ }^{15} \mathrm{~N}$ measurements in blood serum from residents of Malmö, Sweden. Radi- 


\section{Influence of Diet on Bomb-Pulse Dating of Human Plaque}

ation and Environmental Biophysics, doi: 10.1007/ s00411-013-0458-9.

Gonçalves I, Stenström K, Skog G, Mattsson S, Nitulescu M, Nilsson J. 2010. Dating components of human atherosclerotic plaques. Circulation Research 106(6): 1174-7.

Harkness DD, Walton A. 1969. Carbon-14 in the biosphere and humans. Nature 223(5212):1216-8.

Hua Q, Barbetti M. 2004. Review of tropospheric bomb ${ }^{14} \mathrm{C}$ data for carbon cycle modeling and age calibration purposes. Radiocarbon 46(3):1273-98.

Libby WF, Berger R, Mead JF, Alexander GV, Ross JF. 1964. Replacement rates for human tissue from atmospheric radiocarbon. Science 146(3648):1170-2.

Lynnerup N, Kjeldsen H, Heegaard S, Jacobseb C, Heinemeier J. 2008. Radiocarbon dating of the human eye lens crystallines reveal proteins without carbon turnover throughout life. PLOS One 3(1): e1529, doi: 10.1371/journal.pone.0001529.

Marques-Vidal P, Ravasco P, Dias CM, Camilo ME. 2006. Trends of food intake in Portugal, 1987-1999: results from the National Health Surveys. European Journal of Clinical Nutrition 60(12):1414-22.

Meier-Augenstein W. 1999. Applied gas chromatography coupled to isotope ratio mass spectrometry. Journal of Chromatography $A$ 842(1-2):321-71.

Minagawa M. 1992. Reconstruction of human diet $\delta^{13} \mathrm{C}$ and $\delta^{15} \mathrm{~N}$ in contemporary Japanese hair: a stochastic method for estimating multi-source contribution by double isotopic tracers. Applied Geochemistry 7(2): 145-58.

Nash SH, Bersamin A, Kristal AR, Hopkins SE, Church RS, Pasker RL, Luick BR, Mohatt GV, Boyer BB, O'Brien MO. 2012. Stable nitrogen and carbon isotope ratios indicate traditional and market food intake in an indigenous circumpolar population. The Journal of Nutrition, Nutritional Epidemiology 142(1):84-90.

Nydal R, Lövseth K, Syrstad O. 1971. Bomb ${ }^{14} \mathrm{C}$ in the human population. Nature 232(5310):418-21.

O'Connell TC. 1996. The isotopic relationship between diet and body proteins: implications for the study of diet in archaeology [DPhil thesis]. Oxford: University of Oxford.

Reimer PJ, Brown TA, Reimer RW. 2004. Discussion: reporting and calibration of post-bomb ${ }^{14} \mathrm{C}$ data. Radiocarbon 46(3): 1299-304.

Schoeller DA. 1999. Isotope fractionation: Why aren't we what we eat? Journal of Archaeological Science 26(6):667-73.

Schoeller DA, Minagawa M, Slater R, Kaplan IR. 1986. Stable isotopes of carbon, nitrogen and hydrogen in the contemporary North American human food web. Ecology of Food and Nutrition 18(3):159-70.

Skog G. 2007. The single stage AMS machine at Lund University: status report. Nuclear Instruments and Methods in Physics Research B 259(1):1-6.

Skog G, Rundgren M, Sköld P. 2010. Status of the Single Stage AMS machine at Lund University after 4 years of operation. Nuclear Instruments and Methods in Physics Research B 268(7-8):895-97.

Stenström K, Skog G, Nilsson CM, Hellborg R, Svegborn SL, Georgiadou E, Mattsson S. 2010. Local variations in ${ }^{14} \mathrm{C}$ - How is bomb-pulse dating of human tissues and cells affected? Nuclear Instruments and Methods in Physics Research B 268(7-8):1299-302.

Tieszen LL, Boutton TW, Tesdahl KG, Slade NA. 1983. Fractionation and turnover of stable carbon isotopes in animal tissues: implications for $\delta^{13} \mathrm{C}$ analysis of diet. Oecologia 57:32-37.

Ubelaker DH, Buchholz BA. 2005. Complexities in the use of bomb-curve radiocarbon to determine time since death of human skeletal remains. Forensic Science Communications, UCRL-JRNL-212160.

Vanderklift MA, Ponsard S. 2003. Sources of variation in consumer-diet $\delta^{15} \mathrm{~N}$ enrichment: a meta-analysis. Oecologia 136(2):169-82.

Wilks DS. 2006. Statistical Methods in the Atmospheric Sciences. 2nd edition. International Geophysics Series. New York: Academic Press. 